\title{
DILEMMA OF DATING ON LACUSTRINE DEPOSITS IN AN HYPERARID INLAND BASIN OF NW CHINA
}

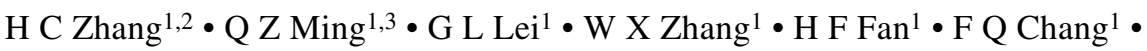 \\ B Wünnemann ${ }^{4} \cdot \mathrm{K}_{\text {Hartmann }}^{4}$
}

\begin{abstract}
Conventional and accelerator mass spectrometry (AMS) radiocarbon, TL, OSL, and IRSL dating results on samples from the cores D100 and I70 from Ejina Basin, one of the most important inland basins in arid-hyperarid NW China, show that it is difficult to determine the ages of sediments at different depths. AMS ages of core D100 samples demonstrate that the sediments at depths from 10 to $90 \mathrm{~m}$ were formed between 14 to $30 \mathrm{kyr}$ BP. The inverted ages from both the D100 and $\mathrm{I} 70$ cores imply that there was a strong reworking of the sediments during and after deposition processes. The inverted ages also indicate drastic fluctuations of groundwater bearing soluble organic matters, which might be related to neotectonic activities and climate changes during the period. Consequently, it is impossible to establish an accurate and reliable chronology for the cores based only on these dates. All AMS ages, if they are reliable and acceptable, indicate a high deposition rate $(5 \sim 8 \mathrm{~mm} / \mathrm{yr})$, and since all TL, OSL, and IRSL ages are much older than those given by AMS, it makes these methods questionable for determining the ages of lacustrine-fluvial-alluvial deposits.
\end{abstract}

\section{INTRODUCTION}

Accurate and reliable dating of lacustrine deposits in arid-hyperarid areas is of crucial importance in reconstructing paleolake and paleoclimate evolution history and in understanding the mechanisms of climate changes, especially abrupt changes of regional-hemispheric hydrological circulation. Because of the relatively undisturbed environments in such areas, the signatures of climatic change might have been strongly imprinted in continuously deposited sections, and such climate signals may present significant indicators of regional and global climatic changes (Zhang et al. 2000).

Geological investigations, including more than 80 drillings, reveal that the sediments of Quaternary age, mostly lacustrine-fluvial-alluvial deposits in Ejina Basin, are up to $300 \mathrm{~m}$ thick (Figure 1). Widely distributed coarse gravels in the upper 2 to $7 \mathrm{~m}$ in a typical area of the Gobi Desert protect the fine-grained lacustrine sediments under the gravel layer from deflation. However, because of the year-round strong winds, this region, together with the nearby Badain Jaran Desert, serves as a prominent source for dust transport (Pye and Zhou 1989).

Recently published results by Hartmann (2003) and Becken et al. (2003) suggest that there were strong, young tectonic activities, which induced relative subsidence and uplifting of the northern part of the basin. This possibly explains the differences in the sedimentation processes between the Gaxun Nur system and the eastern paleolake Juyanze during the Holocene (Hartmann 2003), where our numerous unpublished dating results indicate the presence of strongly reworked deposits in the past and even in the present.

Previously reported preliminary investigations show that high lake levels existed during the late MIS3 in the Gaxun Nur-Sogo Nur areas (Pachur et al. 1995; Wünnemann and Hartmann 2002) and also in the nearby Badain Jaran Desert and Tengger Desert (Yang 2001, 2002; Zhang et al. 2001, 2002, 2004). The literature reveals that the climate situation during the late MIS3 was different in

\footnotetext{
${ }^{1}$ National Laboratory of Western China's Environmental Systems, MOE; College of Earth Sciences and Environments, Lanzhou University, Lanzhou 730000, China; also Nanjing Institute of Geography and Limnology, Chinese Academy of Sciences (CAS), Nanjing 210008, China.

${ }^{2}$ Corresponding author. Email: zhanghc@niglas.ac.cn.

${ }^{3}$ College of Tourist and Geography, Yunnan Normal University, Kunming 650092, China.

${ }^{4}$ Institute for Geographical Sciences, FU Berlin, Malteserstr. 74-100, 12249 Berlin, Germany.
} 


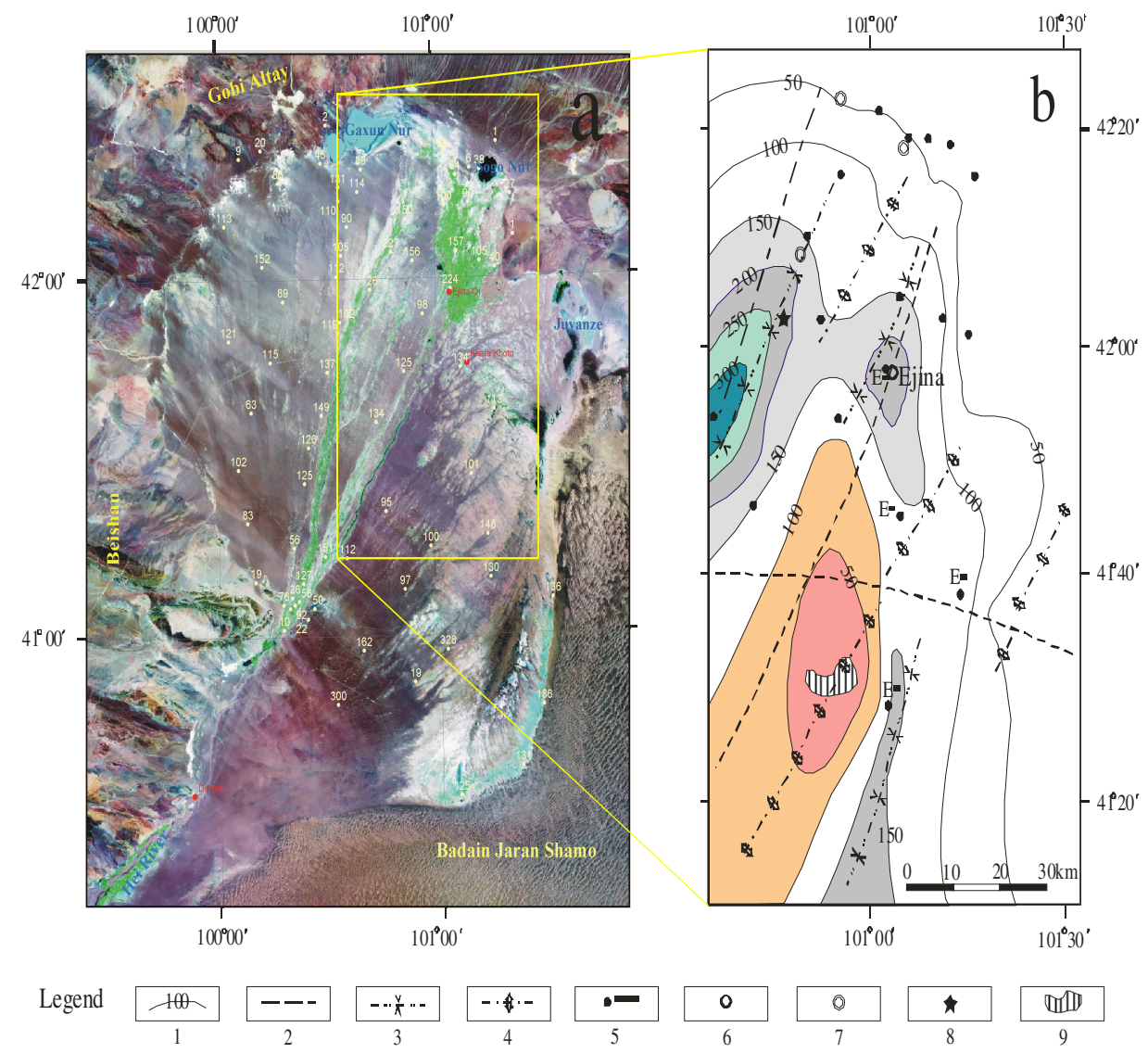

Figure 1 Satellite image of Ejina Basin with location of the D100 core site (Figure 1a, left) and the contour map of the Quaternary deposit (Figure 1b, modified from the Report of the Regional Hydrological Investigation, K-47-24, 1980). The depth of core G21 is $154.92 \mathrm{~m}, \mathrm{G} 20$ (D100 is very close): $231.85 \mathrm{~m}, \mathrm{~S} 4: 345 \mathrm{~m}, \mathrm{E} 1$ : 237.82 m, E2: $134.8 \mathrm{~m}, \mathrm{E} 4: 124.03 \mathrm{~m}$, and E5: $148.3 \mathrm{~m}$. Numbers correspond to the following: 1: contour line; 2: hypothetical basement faulting systems; 3 : subsidence structure; 4: uplifting structure; 5 : deep drilling sites (some of them with numbers); 6: villages; 7: town; 8: site of deep drilling core D100; 9: rock outcrop.

the past in what are now arid-hyperarid areas in NW China (Ma et al. 1998; Peng et al. 1998; Shi et al. 2001, 2002, 2003; Yang and Shi 2003).

Recent conventional and accelerator mass spectrometry (AMS) radiocarbon dating results on drilling core D100-which is $230 \mathrm{~m}$ deep and extrapolated to be $\sim 0.96 \mathrm{Ma}$ at the bottom based on paleomagnetism and TL-IRSL dating methods (Wünnemann et al. 1998) — and supplementary core I70 demonstrate that ${ }^{14} \mathrm{C}$ ages of the cores show frequent age reversals and are much younger than the ages determined by paleomagnetism and TL, IRSL, and OSL dating. The strong discrepancies between ages measured by ${ }^{14} \mathrm{C}$ and paleomagnetism and TL, IRSL, and OSL dating methods raise doubts about the previous chronology establishment of the core and demonstrate the need for further examination of the data.

\section{STUDY AREA}

Ejina (Gaxun Nur) Basin is one of the largest inland basins in arid NW China. Geologically, it belongs to part of the Alashan Plateau and is located in western Inner Mongolia $\left(40^{\circ} 30^{\prime} \mathrm{N}-43^{\circ} 30^{\prime} \mathrm{N}\right.$; 
$\left.99^{\circ} 45^{\prime} \mathrm{E}-101^{\circ} 45^{\prime} \mathrm{E}\right)$. The basin itself is an intramontane accumulation area between the Qilian Mountains in the south and the Gobi-Tianshan Mountains in the north; this area is known as the Badain Jaran Desert (Figure 1a). Both mountain ranges in the north and south are influenced by leftlateral plate motions accompanied by intense vertical displacements due to the ongoing collision of the Indian plate against the Eurasian continent. The sinistral pattern continues northward from the Qilian Mountains via the Hexi Corridor towards the Alashan Plateau (Molnar and Taponnier 1975; Li et al. 1999; Hetzel et al. 2002; Hartmann 2003), forming a "belt of left-lateral transpression" (Dickson Cunningham 1996). Consequently, the Ejina Basin developed as a large pull-apart basin between these structural elements, acting as a base for the Hei River drainage system from the south (NE Tibetan Plateau).

The endorheic Ejina Basin covers an area of $\sim 28,000 \mathrm{~km}^{2}$, while the total catchment of the Hei River system, the only river flowing into the basin that connects with glaciers in the Qilian Mountains, comprises roughly $130,000 \mathrm{~km}^{2}$. The natural climate changes, human damming in the upper reaches, and water extractions for agricultural usage have caused environmental and ecological problems in the area (Gong et al. 1998; Wang and Cheng 1998; Zhang and Ming 2006). There are 3 terminal lakes (Gaxun Nur, Sogo Nur, and Juyanze) distributed in the basin. Sogo Nur is an artificial lake measured as $\sim 30 \mathrm{~km}^{2}$ in area in 2003, and the Juyanze Lake has been shrinking to the small Jinsutu Lake in the NE corner of the basin. Generally speaking, Ejina Basin is a very flat area dipping to the NNE with an altitudinal gradient of $-1.15 \mathrm{~m} / \mathrm{km}$ from Jinta to Ejina.

The Ejina Basin possesses a typical inland hyperarid climate. According to meteorological data from 1951 to 1980 , the annual mean precipitation varies from $37.9 \mathrm{~mm}$ (Ejina Town; $41^{\circ} 57^{\prime} \mathrm{N}$, $101^{\circ} 04 \mathrm{E}^{\prime}$; $940.5 \mathrm{~m}$ asl) to $53.3 \mathrm{~mm}$ (Dingxin; $40^{\circ} 18^{\prime}, 99^{\circ} 35^{\prime} \mathrm{E} ; 1177.4 \mathrm{~m}$ asl), while in the upper catchment of Hei River the precipitation rises to $500 \mathrm{~mm} / \mathrm{yr}$. The annual mean temperatures range between $8.4{ }^{\circ} \mathrm{C}$ in Ejina Town, with a January mean of $-12.5^{\circ} \mathrm{C}$ and a July mean of $26.2{ }^{\circ} \mathrm{C}$, and $8{ }^{\circ} \mathrm{C}$ in Dingxin, with a January mean of $-10.1^{\circ} \mathrm{C}$ and a July mean of $23.9^{\circ} \mathrm{C}$. During wintertime, cold, dry air masses from the anticyclone over Siberia are responsible for extremely low temperatures and strong winds from the north, producing frequent dust storms and contributing to the global climate changes (Jickells et al. 2005; Wang et al. 2005).

\section{MATERIALS AND METHODS}

Core D100 is $230 \mathrm{~m}$ long and was drilled by the Chinese geological investigation group at the center of the northern Ejina Basin $\left(42^{\circ} 06^{\prime} \mathrm{N}, 100^{\circ} 51^{\prime} \mathrm{E}, 940 \mathrm{~m}\right.$ asl) using a rotational drilling system with 3-m-long, 80-120-mm-diameter metal tubes. The core reached the pre-Quaternary basement. The supplementary core $\mathrm{I} 70$ is near core D100, but due to technical reasons core $\mathrm{I} 70$ does not reach the bottom. Once a core segment was retrieved, it was pressed out immediately, halved, described, and finally documented by photographs. Most parts of the core that were drilled are dry and hard, which makes storage and transportation easy and free from further subaerial oxidation. All samples were stored properly, and samples used for dating are 1-cm-thick slices for AMS and 5-cm slices for conventional ${ }^{14} \mathrm{C}$ and TL-OSL-IRSL. They were well protected to avoid possible contamination.

In order to test the reliability and accuracy of the different dating methods (e.g. conventional ${ }^{14} \mathrm{C}$, AMS, and also TL, OSL, and IRSL) at different laboratories, ages were tested of various components (e.g. the alkali [bulk organic carbon] and humic acids) of organic matter from the same sample. Theoretically, the alkali is treated as the true age of the tested sample, while the humic acids may be contaminated easily as soluble matter. AMS dates were conducted at Leibniz Laboratory for Radiometric Dating and Stable Isotope Research at Kiel University in Germany (Lab. serial number: KIA) and Beta Analytic Inc. at Miami, USA (Beta). Conventional ${ }^{14} \mathrm{C}$ analyses were conducted at 
the ${ }^{14} \mathrm{C}$ Laboratory in Leibniz Institute for Applied Geosciences (GGA-Institut), Hannover, Germany (Hv); Guangzhou Institute of Geochemistry, Chinese Academy of Sciences, Guangzhou, China (TL); and IRSL in SKLED, Institute of Geology, China Seismological Bureau, Beijing, China. OSL dates were conducted at the Saxonian Academy of Sciences, Freiberg, Germany.

\section{RESULTS AND DISCUSSION}

All ${ }^{14} \mathrm{C}$, AMS, TL, OSL, and IRSL dates measured are listed in Table 1. It is clear that the ages of different materials from the same sample are different from one another, and strong varieties and reversals exist in the core. Based on the AMS dates, the sediments from 11 to $90 \mathrm{~m}$ of the core D100 can be divided into 5 parts from the upper to the lower core stratigraphy.

Table 1 Dating results of the cores D100 and I70 from Ejina Basin by different laboratories.

\begin{tabular}{|c|c|c|c|c|c|c|}
\hline Sample $n r^{\mathrm{a}}$ & $\begin{array}{l}\text { Depth } \\
\text { (m) }\end{array}$ & Lab nr ${ }^{\mathrm{a}}$ & Material & $\begin{array}{l}{ }^{13} \mathrm{C} \\
(\% \circ)\end{array}$ & $\begin{array}{l}\text { AMS age } \\
\text { kyr BP }\end{array}$ & $\begin{array}{l}\text { TL/IRSL OSL } \\
\text { age kyr BP }\end{array}$ \\
\hline D100-TL1 & 9.32 & TGD-470 & Lake sand & & & $22 \pm 1.8$ \\
\hline D100-2 & 11.13 & Hv20383 & $\begin{array}{l}\text { Bulk } \\
\text { carbonate }\end{array}$ & -3.9 & $(21,265 \pm 0.5)$ & \\
\hline D100-1101 & 11.22 & Beta188774 & Bulk org C & -23.6 & $14.45 \pm 0.1$ & \\
\hline D100-1601 & 16.29 & Beta189674 & Bulk org C & -23 & $14.29 \pm 0.1$ & \\
\hline D100-IRSL1 & 16.36 & Beij1 & Lake sand & & & $29.2 \pm 3.7$ \\
\hline D100-1901 & 19.71 & Beta189675 & Bulk org C & -22.9 & $17 \pm 0.1$ & \\
\hline D100-IRSL2 & 19.73 & Beij2 & Lake sand & & & $41.1 \pm 2.9$ \\
\hline D100-TL2 & 22.05 & TGD-471 & Lake sand & & & $54.5 \pm 5$ \\
\hline D100-3402 & 34.5 & Beta190783 & Bulk org C & -23.2 & $16.86 \pm 0.1$ & \\
\hline D100-3904 & 40.06 & Beta190784 & Bulk org C & -22 & $16.72 \pm 0.1$ & \\
\hline D100-IRSL3 & 44.12 & Beij3 & Lake sand & & & $90 \pm 6.2$ \\
\hline D100-10 & 44.22 & KIA24208 & Bulk org C & -25.03 & $34.82 \pm 0.4$ & \\
\hline D100-10 & 44.22 & KIA24208 & Humic acid & -25.02 & $30+0.8 /-0.7$ & \\
\hline D100-IRSL4 & 60.91 & Beij4 & Lake sand & & & $196 \pm 15$ \\
\hline D100-11 & 65.59 & KIÄ24209 & Bulk org C & -22.86 & $26.41 \pm 0.5$ & \\
\hline D100-11 & 65.59 & KIA24209 & Humic acid & -23.86 & $34.57+1 /-0.9$ & \\
\hline D100-IRSL5 & 71.9 & Beij5 & Lake sand & & & $202 \pm 17$ \\
\hline D100-12 & 72.25 & KIÁ24848 & Bulk org C & -26.83 & $23.75+0.7 /-0.6$ & \\
\hline D100-12 & 72.25 & KIA24848 & Humic acid & -21.55 & $27.57 \pm 0.3$ & \\
\hline D100-13 & 76.99 & KIA25440 & Bulk org C & -27.08 & $27.2+1.3 /-1.1$ & \\
\hline D100-13 & 76.99 & KIA25440 & Humic acid & -25.14 & $20.56+0.4 /-0.3$ & \\
\hline D100-14 & 79.71 & KIA25441 & Bulk org C & -20.09 & $25.64 \pm 0.4$ & \\
\hline D100-14 & 79.71 & KIA25441 & Humic acid & -30.77 & $25.73+1.7 /-1.4$ & \\
\hline D100-IRSL6 & 84.11 & Beij6 & Lake sand & & & $294 \pm 25$ \\
\hline D100-15 & 90.12 & KIÄ25756 & $\begin{array}{l}\text { Bulk } \\
\text { carbonate }\end{array}$ & -4.03 & $(>41.52)$ & \\
\hline D100-8911 & 90.12 & KIA25756 & Bulk org C & -19.08 & $30.71 \pm 0.4$ & \\
\hline I70-16 & 11.77 & Beta188775 & Bulk org C & -23.9 & $8.89 \pm 0.08$ & \\
\hline I70-1470 & 14.7 & Freiberg & Lake sand & & & $146 \pm 10$ \\
\hline I70-17 & 14.8 & Beta 189676 & Bulk org C & -21.1 & $11.18 \pm 0.05$ & \\
\hline I70-2900 & 29 & Freiberg & Lake sand & & & $172 \pm 12$ \\
\hline I70-18 & 29.67 & Beta190786 & Bulk org C & -23 & $6.97 \pm 0.06$ & \\
\hline I70-3850 & 38.5 & Freiberg & Lake sand & & & $230 \pm 16$ \\
\hline I70-5050 & 50.5 & Freiberg & Lake sand & & & $281 \pm 23$ \\
\hline
\end{tabular}

${ }^{a}$ Note: D100 is the main drilling core in Ejina Basin, and I70 is the short core near core D100. TGD-TL: Guangzhou Institute of Geochemistry, Chinese Academy of Sciences, Guangzhou, China; Hv-Conv.14-C: Leibniz Institute for Applied Geosciences (GGA-Institut), Hannover, Germany; Beta-AMS: Beta Analytic Inc., Miami, USA; BeijIRSL: SKLED, Institute of Geology, China Seismological Bureau, Beijing, China; KIA-AMS: Leibniz Laboratory for Radiometric Dating and Stable Isotope Research, Kiel University, Germany; Freiberg-OSL: Saxonian Academy of Sciences, Freiberg, Germany. 
- Part 1, ages of the sediments between 11 and $40 \mathrm{~m}$ deep in the core range from 14 to $17 \mathrm{kyr}$ BP. The conventional ${ }^{14} \mathrm{C}$ dating on bulk carbonate at $9.32 \mathrm{~m}$ is $\sim 21 \mathrm{kyr} \mathrm{BP}$; it is $\sim 6000 \mathrm{yr}$ older than the extrapolated age of organic matter and can be treated as the "dead/old carbon effect."

- Part 2, AMS age at $44.22 \mathrm{~m}$ in the core is $34.82 \pm 0.4 \mathrm{kyr}$ BP, showing a big jump to the age of overlain deposits. Age of the humic acid is $30+0.8 /-0.7 \mathrm{kyr}$ BP, which is $\sim 5000$ yr younger than the age given by bulk organic carbon (Figure $2 b$ ) and implies the influence of downward movement on the young soluble organic matter.
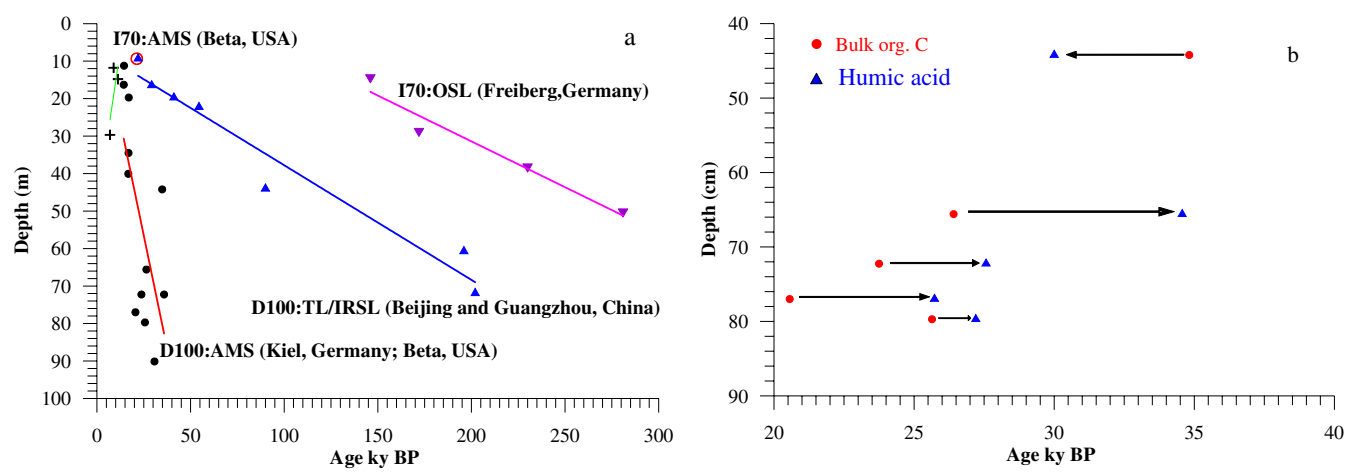

Figure 2 The relationship between age and depth in cores D100 and I70 (Figure 2a) and variations of the ages given by bulk organic carbon (alkali residue) and humic acid (Figure 2b).

- Part 3, the sample from $65.59 \mathrm{~m}$ gives an AMS age of $26.41 \pm 0.5 \mathrm{kyr}$ BP. The age of humic acid is $34+1 /-0.9 \mathrm{kyr} \mathrm{BP}$, which is $\sim 8000$ yr older than the age given by bulk organic carbon and implies influence of upward movement on the old soluble organic matters.

- Part 4, there are 3 pairs of AMS ages between the depth of $72.25 \mathrm{~m}$ and $79.71 \mathrm{~m}$ that give a complex picture. The age of bulk organic carbon from the sample taken at $72.25 \mathrm{~m}$ is $23+0.7 /$ $-0.6 \mathrm{kyr} \mathrm{BP}$, which is younger than the age measured by humic acid $(27.57 \pm 0.3 \mathrm{kyr} \mathrm{BP})$ and implies the influence of underground water flowing through the area bearing older soluble organic carbon. Because this age is similar to the age of the sample at $76.99 \mathrm{~m}(27.2+1.3 /-1.1$ kyr BP), it is therefore possible that the soluble organic carbon might have come from the original deposit accumulated at $76.99 \mathrm{~m}$, even though the sample itself possibly is a reworked deposit. The AMS age of bulk organic carbon at $79.71 \mathrm{~m}$ is $25.64 \pm 0.4 \mathrm{kyr}$ BP. This age is comparable to that of the humic acid, which is $25.73+1.7 /-1.4 \mathrm{kyr}$ BP. The age indicates that there is no influence of soluble organic matter on the sample at this depth, and the date can be regarded as a reliable one. Another interesting fact that should be discussed here is that even though the age at $72.25 \mathrm{~m}$ is younger than that at $76.99 \mathrm{~m}$, the age at $76.99 \mathrm{~m}$ is older than that at $79.71 \mathrm{~m}$. The humic acid age at $72.25 \mathrm{~m}$ is older than both that at $76.99 \mathrm{~m}$ and $79.71 \mathrm{~m}$ (Figure $2 \mathrm{~b}$ ). These phenomena demonstrate that the materials deposited at $\sim 77 \mathrm{~m}$ depth are reworked sediments, and at the same time, the soluble organic materials from this part have moved upward, making the humic acid age in the sample older because of overlain sediments. However, the much younger age of the humic acid at $\sim 80$-m core depth possibly has been influenced by organic carbon-bearing groundwater flowing horizontally much later on.

- Part 5, at $90.12 \mathrm{~m}$ depth, the age of bulk organic carbon is $30.71 \pm 0.4 \mathrm{kyr}$ BP, while the bulk carbonate results in an AMS age of older than $41.52 \mathrm{kyr}$ BP. This older carbonate age can be treated as the "dead/old carbon effect." Since the age at $79.71 \mathrm{~m}$ is considered reasonable, the age of bulk organic carbon from this part is acceptable. 
There are 3 AMS dates on the supplementary core I70. Compared with the ages for core D100, it seems that the AMS age at the $29.67 \mathrm{~m}$ depth is too young and is possibly reworked deposits.

From Table 1, it is clear that all ages obtained by TL, OSL, and IRSL methods are considerably older than AMS ages, even though all TL, OSL, and IRSL ages for both cores have reasonable linearity regressions (Figure 2a). One of the possible explanations is that the TL, OSL, and IRSL signals possessed by old material remain after reposition. Two facts make the TL, OSL, and IRSL dates questionable: 1) If these dates are correct, then the alignment of the core I70 ages to the core D100 ages at $\sim 52 \mathrm{~m}$ depth requires a $\sim 37-\mathrm{m}$ difference, implying the sediments at the drilling site of $\mathrm{I} 70$ should have been uplifted or core D100 would have relatively subsided by $37 \mathrm{~m}$, but geological evidence and our knowledge does not support this; 2) If these dates are correct, then all the AMS dates from core I70 and D100 are wrong. Unfortunately, this seems not to be true. Based on these arguments, we concluded that TL, OSL, and IRSL methods are not suitable to date the lacustrine-fluvial deposits, in our case at least. Their applicability to measure the ages of such sediments is an open question and needs further study.

It is useful to date both the bulk organic carbon (alkali residual) and humic acid of the tested samples. There is always the possibility of humic acid contamination because such kinds of soluble matter not only can move horizontally, but also vertically along with the fluctuation of groundwater. This problem can be treated with alkali extractions and by then dating the alkali-insoluble fraction. The dating results of humic acid can provide information about the influence of groundwater that bears soluble organic carbon.

Geochemical measurements show that the total organic carbon (TOC) content of the core D100 samples is low (between $0.2-1.6 \%$ by dry weight, maximum $2 \%$ ). Given the low organic carbon content of the samples, if the tested samples are so strongly contaminated that the age of the sample changes completely, it would require several times the amount of material to have sufficient carbon remaining after pretreatment. At the Beta laboratory, all samples for dating were given a series of hot acid leaches to remove carbonates completely and then were sieved to $<180$ microns to remove any macrofossils, roots, etc. For example, a sample of $\sim 20 \mathrm{~g} \mathrm{D100-1101}$ is pretreated to $14.0 \mathrm{~g}$, and $4.3 \mathrm{~g}$ of such pretreated material is used to produce $3.8 \mathrm{cc} \mathrm{CO}_{2}(\sim 0.05 \%$ carbon by weight $)$ and produces an age of $14.45 \pm 0.1 \mathrm{kyr} \mathrm{BP} ; 6.0 \mathrm{~g}$ of sample I70-16 is pretreated to $2.9 \mathrm{~g}$, and $2.6 \mathrm{~g}$ of this pretreated material is combusted to produce $5.2 \mathrm{cc} \mathrm{CO}_{2}(\sim 0.11 \%$ carbon by weight) and produces an age of $8.89 \pm 0.08 \mathrm{kyr}$ BP.

Contamination levels by more recent carbon (modern, essentially carbon from post-AD 1950) would, however, have to be pervasive to cause the ages yielded if the "true ages" were indeed as old as indicated by the other techniques (essentially ${ }^{14} \mathrm{C}$-dead). For the age of sample D100-1101 to have been older than $50 \mathrm{kyr}$, it would require at least $10-15 \%$ modern contamination by weight to yield an age of 14,500 BP. Similarly, if the age of sample I70-16 would have been older than $50 \mathrm{kyr}$, it would require at least 15-20\% modern contamination by weight to yield an age of $8900 \mathrm{BP}$. Modern carbon contamination in our samples is out of consideration because none of these samples appear to have been humic stained from overlying sediments; the samples were, in fact, quite clean and appeared somewhat oxidized. This was apparent in the carbon contents that were on the lower end. Furthermore, we are confident about the sampling, storage, transportation, and preparation procedures, assuring that any chances of modern carbon contamination have been avoided.

AMS ages from core D100 show strong reversals, which might be contributing to the active neutectonic movements and climatic fluctuations. High paleolake levels during the late MIS3 in the studied areas imply increased precipitation and water recharge into the basin accompanied by the 
increased water transportation capacity and resulted in a rapid material accumulation rate $(5 \sim 8 \mathrm{~mm} /$ $\mathrm{yr}$, that is $\sim 10$ times higher than a normal deposition rate in the lakes). The climate instability and neutectonic activities may facilitate such processes and make the components of the deposited materials more complex and, furthermore, may make the age determination more difficult.

\section{CONCLUSIONS}

It is difficult to date samples from arid-hyperarid regions not only because so few well-developed and preserved lacustrine deposits exist in such areas, but also because of the low organic carbon content in the sediments. However, when the lacustrine deposits exist, study of such deposits is of great importance, as they not only record paleolake development history, but also the climate changes, especially hydrological circulation readjustment before, during, and after the lake evolutions. In such studies, chronology establishment is one of the most important tasks even though it is quite difficult to do (Geyh et al. 1999; Schramm et al. 2000; Zhang et al. 2006).

Applying conventional and AMS ${ }^{14} \mathrm{C}$ and TL, OSL, and IRSL methods to date the lacustrine deposits from 2 cores drilled at Ejina Basin in NW China suggests that strong, frequent reworking and redeposition of sediments in the core sites occurred. Even using suitable materials and appropriate components for ${ }^{14} \mathrm{C}$ dating methods, the ${ }^{14} \mathrm{C}$ ages of samples still show massive reversals; hence, it is difficult to establish reliable high-resolution chronologies. The active reworking processes resulted both from strong neotectonic movements and abrupt climatic changes in the area, generating a rapid accumulation rate in the basin, especially at the drilling sites, which are located at the edge of the deposition or subsidence center (Figure 1b). On the other hand, our study shows that TL, OSL, and IRSL dating methods are not suitable to date samples in the area because, at the very least, their reliability and accurate are questionable. The benefit from this study is that we will be guided by the experience of learning to choose the right section/drilling cores and samples to get reasonable dates. For samples that have not been reworked, redeposited, or formed from a mixture of various ages of carbon (multiple sources), influenced by groundwater, or that are overlain by highly humic zones, ${ }^{14} \mathrm{C}$ dating on the "bulk organic" fraction typically should provide better results.

\section{ACKNOWLEDGMENTS}

This study was supported by NSFC (40371117), the Hundred Talent Project by Chinese Academy of Sciences (C250076), and the State Key Laboratory of Loess and Quaternary Geology, Institute of Earth Environments (SKLLQG0514). Special thanks to Dr P Grootes and Dr R E Hatfield for discussions on the results, and Mark McClure for carefully editing the original version.

\section{REFERENCES}

Becken M, Hölz S, Polag D, Fiedler-Volmer R, Burkhardt H. 2003. Electromagnetic investigation in the Gaxun Nur Basin, Inner Mongolia, China. In: Mischke S, Wünnemann B, Riede F, editors. International Symposium - Environmental Change in Central Asia. Dept. of Earth Sciences, Berlin. Abstracts. p 8-10.

Dickson Cunningham W, Windley BF, Dorjnamjaa D, Badamgarov J, Saandar M. 1996. Late Cenozoic transpression in southwestern Mongolia and the Gobi Altai-Tien Shan connection. Earth and Planetary Science Letters 140:67-81.

Geyh MA, Grosjean M, Nuñez L, Schotterer U. 1999. Radiocarbon reservoir effect and the timing of the

Late-Glacial/Early Holocene humid phase in the Atacama Desert (northern Chile). Quaternary Research 52:143-53.

Gong JD, Dong GR, Li S, Gao SY, Xiao HL, Shen JY. 1998. Degradation of physical environment and its control in Ejina Oasis at the lower reaches of Heihe River. Journal of Desert Research 18(1):44-50.

Hartmann K. 2003. Spätpleistozäne und holozäne Morphodynamik im nördlichen Gaxun Nur Becken, Innere Mongolei, NW China [PhD dissertation]. Berlin: FU. 1-123. In German.

Hetzel R, Niedermann S, Tao M, Kubik PW, Ivy-Ochs S, Gao B, Strecker MR. 2002. Low slip rates and long- 
term preservation of geomorphic features in Central Asia. Nature 417(6887):428-32.

Jickells TD, An ZS, Andersen KK, Baker AR, Bergametti G, Brooks N, Cao JJ, Boyd PW, Duce RA, Hunter KA, Kawahata H, Kubilay N, laRoche J, Liss PS, Mahowald N, Prospero JM, Ridgwell AJ, Tegen I, Torres R. 2005. Global iron connections between desert dust, ocean biogeochemistry and climate. Science 308(5718):67-71.

Li Y, Yang J, Tan L, Duan F. 1999. Impact of tectonics on alluvial landforms in the Hexi Corridor, NW China. Geomorphology 28:299-308.

Ma YZ, Zhang HC, Li JJ, Pachur HJ, Wünnemann B. 1998. A study on the palynoflora and climatic environment during Late Pleistocene in Tengger Desert. Acta Botanica Sinica 40(9):871-9. In Chinese with English abstract.

Molnar P, Taponnier P. 1975. Cenozoic tectonics of Asia: effects of a continental collision. Science 189:419-26.

Pachur HJ, Wünnemann B, Zhang HC. 1995. Lake evolution in the Tengger Desert, northwestern China, during the last 40,000 years. Quaternary Research 44(2): $171-81$.

Peng JL, Zhang HC, Ma YZ. 1998. Late Pleistocene limnic ostracods and their environmental significance in the Tengger Desert, northwestern China. Acta Micropalaeontologica Sinica 15(1):22-30.

Pye K, Zhou LP. 1989. Late Pleistocene and Holocene eolian dust deposition in north China and the northwest Pacific Ocean. Palaeogeography, Palaeoclimatology, Palaeoecology 73:11-23.

Schramm A, Stein M, Goldstein SL. 2000. Calibration of the ${ }^{14} \mathrm{C}$ time scale to $>40$ ka by ${ }^{234} \mathrm{U}-{ }^{230} \mathrm{Th}$ dating of Lake Lisan sediments (last glacial Dead Sea). Earth and Planetary Science Letters 175(1-2):27-40.

Shi YF, Yu G. 2003. Warm-humid climate and transgressions during 40-30 ka B.P. and their potential mechanisms. Quaternary Sciences 1:1-11.

Shi YF, Yu G, Liu XD, Li B, Yao T. 2001. Reconstruction of the 30-40 ka BP enhanced Indian monsoon climate based on geological records from the Tibetan Plateau. Palaeogeoraphy, Palaeoclimatology, Palaeoecology 169:69-83.

Shi YF, Jia YL, Yu G, Yang DY, Fan YQ, Li SJ, Wang YF. 2002. Features, impacts and causes of the high temperature and large precipitation event in the Tibetan Plateau and its adjacent area during 40-30 ka BP. Journal of Lake Sciences 14(1):1-11.

Wang GX, Cheng GD. 1998. Changes of hydrology and ecological environment during late 50 years in Heihe River Basin. Journal of Desert Research 18(3):233-8.

Wang YQ, Zhang XY, Arimoto R, Cao JJ, Shen ZX. 2005. Characteristics of carbonate content and carbon and oxygen isotopic composition of northern China soil and dust aerosol and its application to tracing dust sources. Atmospheric Environment 39(14):2631-42.

Wünnemann B. 1999. Untersuchungen zur Paläohydrographie der Endseen in der Badain Jaran- und Tengger Wüste, Innere Mongolei, Nordwest-China [Habilitation thesis] Berlin: FU. 236 p. In German.

Wünnemann B, Hartmann K. 2002. Morphodynamics and paleohydrography of the Gaxun Nur Basin, Inner Mongolia, China. In: Lehmkuhl F, Busche D, Wünnemann B, editors. Zeitschrift für Geomorphologie, Supplementbände, Band 126. Stuttgart: E Schweizerbart'sche Verlagsbuchhandlung, Science Publishers. p 147-68.

Wünnemann B, Pachur H-J, Zhang HC. 1998. Climatic and environmental changes in the deserts of inner Mongolia, China, since the Late Pleistocene. In: Alsharhan AS, Gleenie KW, Whittle GL, editors. Quaternary Deserts and Climatic Changes. Rotterdaman and Brookfield: AA Balkema. p 381-94.

Yang XP. 2000. Landscape types and its formation mechanism in the Badain Jaran Desert and its surrounding areas. Journal of Desert Research 20(2):166-70.

Yang XP. 2002. Water chemistry of the lakes in the Badain Jaran Desert and their Holocene evolution. Quaternary Sciences 22(2):97-104.

Yang B, Shi YF. 2003. Warm-humid climate in northwest China during the period of 40 30 ka B.P.: geological records and origin. Quaternary Sciences 1:60-8.

Zhang HC, Ming QZ. 2006. Hydrology and lake evolution in hyperarid northwestern China and the mystery of megadune formation in Badain Jaran Desert. Advances in Earth Science 21(5):532-8. In Chinese.

Zhang HC, Ma YZ, Wünnemann B, Pachur H-J. 2000. A Holocene climatic record from arid northwestern China. Palaeogeoraphy, Palaeoclimatology, Palaeoecology 162:389-401.

Zhang HC, Ma YZ, Li JJ, Qi Y, Chen GJ, Fang HB, Wünnemann B, Pachur H-J. 2001. Palaeolake evolution and abrupt climate changes during last glacial period in NW China. Geophysical Research Letters 28(16): 3203-6.

Zhang HC, Wünnemann B, Ma YZ, Peng J, Pachur H-J, Li J, Qi Y, Chen G, Fang H, Fenge Z. 2002. Lake level and climate change between 42,000 and $18,000{ }^{14} \mathrm{C} \mathrm{yr}$ B.P. in the Tengger Desert, NW China. Quaternary Research 58(1):62-72.

Zhang HC, Peng JL, Ma YZ, Chen GJ, Feng Z-D, Li B, Fan HF, Chang FQ, Lei GL, Wünnemann B. 2004. Late Quaternary palaeolake levels in Tengger Desert, NW China. Palaeogeoraphy, Palaeoclimatology, Palaeoecology 211:45-58.

Zhang HC, Li B, Yang MS, Lei GL, Ding H, Niu J, Fan HF, Zhang WX, Chang FQ. 2006. Dating paleosol and animal remains in loess deposits. Radiocarbon 48(1): $109-16$. 